\title{
Sosialisasi Disaster Management Bagi Ibu Rumah Tangga
}

\author{
Dwi Putra Buana Sakti* Lalu Suparman, Hermanto, Junaidi Sagir
}

Fakultas Ekonomi dan Bisnis, Universitas Mataram, Mataram, Indonesia

\section{Article history}

Received: 30-12-2020

Revised: 18-03-2021

Accepted: 21-06-2021

*Corresponding Author:

Dwi Putra Buana,

Fakultas Ekonomi dan Bisnis,

Universitas Mataram,

Mataram, Indonesia;

Email:

dwiputrabs@unram.ac.id
Abstract: The concept of disaster management is growing after realizing the impact caused by the disaster. One of the areas on the island of Lombok that was affected by the 2018 earthquake is the North Lombok Regency. Located in an area prone to earthquakes, efforts are needed to minimize the risk of a disaster occurring. One of them is through community service activities in the form of disaster management socialization to housewives. Housewives are deemed necessary to be given socialization because the phenomenon shows that the involvement of housewives in disaster management is still minimal. In several disaster events, it is seen that the role of housewives is more often the object of disaster management. Women are still considered as the weak and do not have any power when a disaster occurs. Referring to this phenomenon, this socialization is aimed at educating housewives about disaster management in order to increase their knowledge and capacity about disaster management. This socialization was carried out using lecture and discussion methods related to the following materials: (i) disaster management; (ii) disaster risk, and (iii) regional disaster management organization. The output of this activity is an increase in the understanding and capacity of housewives about disaster management, disaster risk and knowledge of disaster management organizations in the regions.

Keywords: disaster management; disaster risk; housewives; regional disaster management organization

Abtrak: Konsep manajemen bencana (disaster management) semakin berkembang setelah disadarinya dampak yang ditimbulkan akibat bencana tersebut. Salah satu wilayah di Pulau Lombok yang terdampak bencana gempa bumi tahun 2018 adalah wilayah Kabupaten Lombok Utara. Terletak di area yang rentan terhadap gempa bumi, maka dibutuhkan upaya untuk meminimalisir risiko bencana yang terjadi. Salah satunya melalui kegiatan pengabdian kepada masyarakat dalam bentuk sosialisasi manajemen bencana (disaster management) kepada ibu rumah tangga. Ibu rumah tangga dipandang perlu diberikan sosialisasi karena fenomena menunjukkan keterlibatan ibu rumah tangga dalam manajemen bencana masih minim. Di beberapa kejadian bencana yang terjadi, terlihat peran ibu rumah tangga lebih sering sebagai objek dalam manajemen bencana. Perempuan masih dianggap sebagai pihak yang lemah dan tidak memiliki daya apa pun ketika terjadi bencana. Merujuk pada fenomena itu, maka sosialisasi ini ditujukan untuk memberi edukasi kepada ibu rumah tangga mengenai manajemen bencana agar dapat meningkatkan pengetahuan dan kapasitas mereka tentang manajemen bencana. Sosialisasi ini dilaksanakan dengan metode ceramah dan diskusi terkait materi: (i) manajemen bencana; (ii) risiko bencana, dan (iii) organisasi penyelenggara penanggulangan bencana di daerah. Luaran kegiatan ini adalah meningkatnya pemahaman dan kapsitas ibu rumah tangga tentang manajemen bencana, risiko bencana dan mengetahui organisasi penanggulangan bencana di daerah.

Kata Kunci: manajemen bencana; risiko bencana; ibu rumah tangga; organisasi penyelenggara penanggulangan bencana daerah 


\section{PENDAHULUAN}

Keterlibatan peran perempuan terutama ibu rumah tangga dalam mengelola bencana masih perlu ditingkatkan. Beberapa kejadian bencana dalam dua tahun terakhir menunjukkan ibu rumah tangga diposisikan dalam peran domestik. Ibu rumah tangga masih dinggap sebagai perempuan yang lemah dan tidak berdaya ketika bencana terjadi.

Optimalisasi partisipasi masyarakat idealnya melibatkan seluruh komponen masyarakat baik laki-laki maupun perempuan (Susilowati dan Siswanta, 2016). Gempa Lombok tahun 2018 lalu, menimbulkan korban jiwa dalam jumlah yang cukup besar terutama korban perempuan dan anakanak. Seringkali penanganan bencana kurang memperhatikan kebutuhan dan keterlibatan perempuan, padahal perempuan dan anak-anak merupakan kelompok yang rentan terhadap bencana (Enarson dan Chakrabarti, 2009). Dalam beberapa kasus bencana, perempuan terdampak resiko bencana yang lebih besar dibandingkan yang dialami oleh laki-laki (Resillience Development Initiative, 2011). Selain itu, pengelola bencana yang didominasi laki-laki kurang memahami kebutuhan yang spesifik bagi perempuan. Situasi ini menjadi lebih buruk ketika keterlibatan perempuan dalam kegiatan penanganan bencana, termasuk dalam fase tanggap darurat, rehabilitasi dan rekonstruksi, serta mitigasi bencana kurang dipertimbangkan (Hidayati, 2012)

Sekaitan dengan itu, peningkatan kapasitas perempuan dalam menghadapi bencana harus terus diupayakan. Suksesnya program mitigasi berbasis masyarakat salah satunya ditentukan oleh keikutsertaan perempuan didalamnya. Perempuan menghabiskan waktu yang lebih lama di rumah dibanding dengan laki-laki. Tidak jarang, mereka berperan ganda sekaligus sebagai ibu rumah tangga dan pencari nafkah.

Desa Gondang Kecamatan Gangga Kabupaten Lombok Utara merupakan salah satu lokasi yang terdampak bencana gempa bumi cukup parah. Kejadian bencana di tahun 2018 yang lalu menunjukkan peran perempuan masih diabaikan ketika terjadi bencana. Padahal mereka juga memainkan peran yang penting dalam semua tahap bencana. Mereka lebih sering dipandang sebagai objek dalam situasi bencana. Beberapa masalah yang teridentifikasi adalah: (i) pemahaman ibu rumah tangga yang terdampak bencana tentang manajemen bencana masih rendah, sehingga berdampak pada kesiapan mereka untuk menghadapi bencana; (ii) pemahaman ibu rumah tangga yang terdampak bencana mengenai resiko bencana masih rendah; (iii) ibu rumah tangga yang terdampak bencana sebagian besar belum mengenal dan mengetahui keberadaan lembaga penyelengga penanggulangan bencana tingkat daerah.

Kegiatan sosialisasi ini ditujukan untuk (i) memberikan pemahaman tentang manajemen bencana bagi ibu rumah tangga; (ii) memberikan pemahaman tentang resiko bencana bagi ibu rumah tangga; dan (iii) mengenalkan lembaga penyelenggara penanggulangan bencana tingkat daerah. Terlaksananya kegiatan ini diharapkan dapat memberi manfaat bagi ibu rumah tangga terdampak bencana, yaitu (i) meningkatnya pemahaman ibu rumah tangga tentang manajemen bencana; (ii) meningkatnya pemahaman ibu rumah tangga tentang resiko bencana; dan (iii) ibu rumah tangga mengetahui lembaga penyelenggara penanggulangan bencana yang ada di tingkat daerah.

\section{METODE}

Kegiatan dilaksanakan dalam bentuk sosialisasi. Metode ceramah digunakan untuk: (a) menjelaskan materi disaster manajemen, (b) menjelaskan materi tentang manajemen resiko, (c) menginformasikan tentang eksistensi Badan Penanggulan Bencana Daerah tingkat kabupaten. Sesi tanya jawab digunakan untuk memperjelas materi yang diterima. 


\section{HASIL DAN PEMBAHASAN}

Sosialisasi dilaksanakan di rumah salah seorang warga Dusun Pendagi Desa Gondang Kecamatan Tanjung Kabupaten Lombok Utara pada tanggal 9 Agustus 2020. Materi sosialisasi yang disampaikan adalah manajemen bencana, risiko bencana dan organisasi penyelenggara penanggulangan bencana daerah. Kegiatan sosialisasi dilaksanakan dengan mengikuti protokol kesehatan yang berlaku disaat pandemi covid-19. Hasil pelaksanaan sosialisasi secara garis besar dilaporkan berikut ini.

a) Peserta Yang Hadir.

Seluruh peserta yang diundang datang untuk menghadiri kegiatan sosialisai ini. Dengan demikian target peserta yang hadir terpenuhi $100 \%$.

b) Ketercapaian Target Sosialisai

Dalam pelaksanaan kegiatan sosialisasi ini, kepada peserta diberikan materi terkait dengan manajemen bencana, resiko bencana dan lembaga penyelenggara penanggulangan bencana daerah. Seluruh materi dapat diterima, dicerna dan dipahami peserta dengan baik. Jumlah peserta proporsional dengan jumlah anggota tim pengabdi yang berperan sebagai narasumber turut menunjang pelaksanaan sosialisasi menjadi lebih kondusif. Hal ini didukung oleh antusiasme peserta untuk mengikuti kegiatan ini hingga berakhir. Dilihat dari ketercapaian target tujuan sosialisasi, dapat dinilai baik (90\%) ditunjukkan oleh peningkatan pemahaman peserta.

c) Ketercapaian Target Materi

Pelaksanaan kegiatan melibatkan seluruh anggota tim pengabdian kepada masyarakat yang terdiri dari 4 (empat) orang. Sesi tanya jawab dilakukan bersamaan dengan penyajian materi. Peserta dapat secara langsung mengajukan pertanyaan ataupun menyampaikan pengalaman yang berkaitan dengan bencana.

d) Faktor Penghambat

Kondisi pandemic covid-19 mengharuskan kegiatan sosialisasi ini dilangsungkan dengan menerapkan protocol kesehatan yang berlaku. Semua yang terlibat diharuskan menggunakan masker dan menggunakan hand sanitizer yang disediakan tim pengabdi kepada masyarakat.

\section{e) Faktor Pendukung}

1. Komitmen dan antusiasme peserta yang tinggi untuk menghadiri sosialisasi in ditengah pandemic covid-19 sangat menggembirakan bagi tim pengabdian kepada masyarakat.

2. Adanya dukungan dari ketua RT setempat sangat membantu terlaksananya kegiatan ini.

3. Kesediaan ibu Istianah untuk menyediakan tempat bagi terselenggaranya kegiatan ini sangat membantu tim pengabdian kepada masyarakat.

4. Komunikasi di antara anggota tim berlangsung lancar dan efektif sehingga koordinasi tim pada proses persapan, pembagian materi, dan pelaksanaan sosialisasi dapat berlangsung sesuai rencana
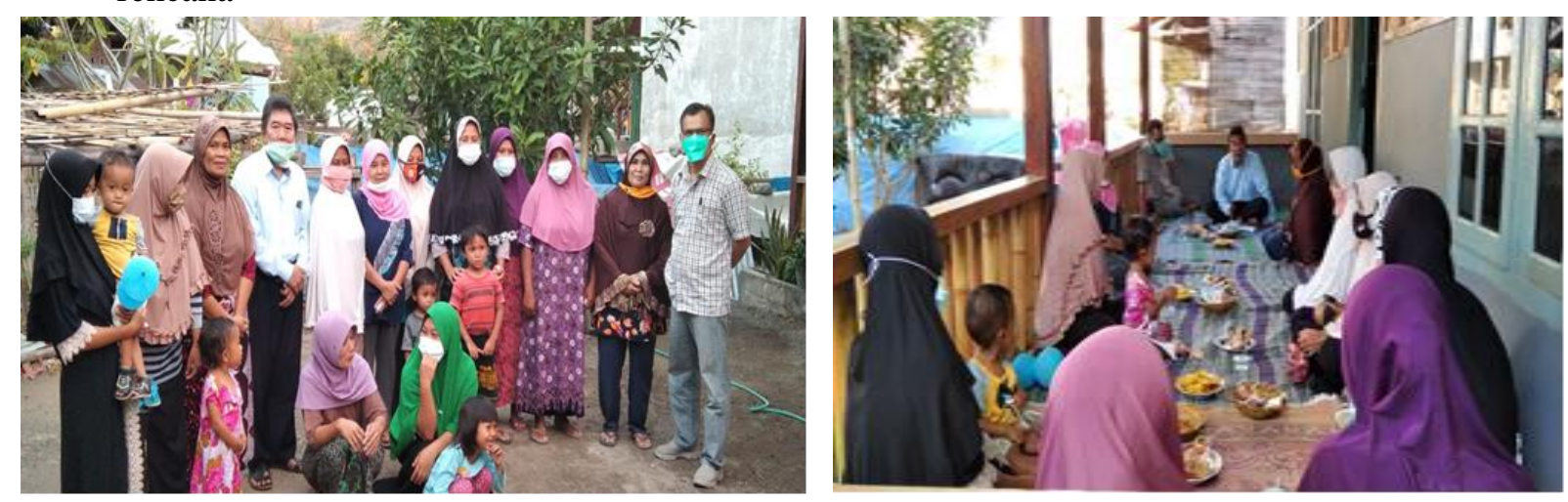

Gambar Kegiatan Sosialisasi 


\section{KESIMPULAN DAN SARAN}

\section{Kesimpulan}

Berdasarkan pada pelaksanaan sosialisasi disaster management untuk meningkatkan kapasitas ibu rumah tangga dalam menghadapi resiko bencana dan uraian sebelumnya di atas, disimpulkan beberapa hal yakni Kegiatan sosialisasi ini memberikan pemahaman kepada ibu rumah tangga yang terdampak bencana mengenai manajemen bencana, resiko bencana dan keberadaan lebaga penyelenggara penanggulangan bencana di daerah. Selain itu juga Ibu rumah tangga yang terdampak bencana lebih memahami tentang menghadapi situasi bencana dan terkait pertolongan pertama dalam menghadapi suatu bencana yang terjadi dan bagaimana cara menghadapi kewaspadaan mitigasi bencana.

\section{Saran}

Saran yang dapat disampaikan penulis yakni bagi Badan Penanggulangan Bencana Daerah (BPBD) Kabupaten Lombok Utara sebaiknya melakukan pendekatan mitigasi bencana yang berbasis pengetahuan dan pemahaman masyarakat diintegrasikan dengan mitigasi ilmiah, dan bagi warga masyarakat yang terdampak bencana, harus mengikuti dan mematuhi petunjuk pihak Badan Penanggulangan Bencana Daerah (BPBD) Kabupaten Lombok Utara tentang tanda-tanda ilmiah akan terjadinya bencana.

\section{Ucapan Terima Kasih}

Tim pengabdi menyampaikan ucapan terimakasih kepada Fakultas Ekonomi dan Bisnis Universitas Mataram serta Lembaga Penelitian dan Pengabdian Kepada Masyarakat Universitas Mataram yang mendanai pelaksanaan kegiatan sosialisasi ini hingga terlaksana dengan baik sesuai surat perjanjian pelaksanaan kegiatan pengabdian kepada masyarakat nomor: 2033/UN18/LPPM/2020.

\section{DAFTAR PUSTAKA}

BMKG. (2018). Gempa Bumi Susulan Lombok. Personnal Communication.

BNPB. (2018). Laporan Dampak dan Penanganan Gempabumi Lombok 2018.

Enarson, E., \& Chakrabarti., P. G. D. (2009). Women Gender and Disaster Global Issues and Initiatives. India: Sage Publications Pvt.Ltd

Hidayati, D. (2012). "Akses dan Keterlibatan Perempuan dan Laki-laki Dalam Penanganan Bencana" dalam Pengelolaan Bencana Berbasis Gender: Pembelajaran Dari Gempa Bantul 2006. Editor Deny Hidayati. Jakarta: PT Dian Rakyat dan PPK-LIPI.

Susilowati, Fitri \& Siswanta, Lilik (2016). Peningkatan Kapasitas Masyarakat

Dalam Menghadapi Risiko Bencana Berbasis Gender. Jurnal Semar Vol5 No1 2016.

Resillience Development Initiative. 2011. Integrasi Rehabilitasi Sosio- Ekonomi Penduduk Setelah Gunung Merapi Tahun 2010 terhadap Perencanaan Pemulihan. Working Paper Series No. 7. April 2014. 